\title{
手書き文字の直線性と曲線性に注目した筆者識別の試み
}

\author{
非会員 佐藤 剛 (アンリッ) \\ 正員 宮川道夫（新潟大） \\ 非会員 石渡正倫 (NTTデータ)
}

\section{An Attempt of Individual Identification from Handwritten Characters \\ Based on the Linear- and Curvilinear-Features}

\begin{abstract}
Tsuyoshi Satoh, Non Member (Anritsu), Michio Miyakawa, Member (Niigata University) and Masamichi Ishiwata, Non Member (NTT Data)
\end{abstract}

The importance of swift and correct identification of individuals is increasing as a key technology to gain access various kinds of information. Specific features appeared in handwritten characters can be used to discriminate a person from the others without invading privacy. This paper deals with the individual identification from handwritten characters in off-line systems. An effective method to extract the specific features appeared in the straight and/or the curved part of handwritten characters is described in this paper. Our feature extraction method is based on calculation of the length and inclination of straight-lines and parameters of the circular arcs that are found in the binarized and thinned lines of the characters. Since the distribution of those specific features depends on the writer, the distribution pattern can be used for the purpose of individual identification. The effectiveness of this method is examined experimentally. The result of our identification experiments enabled us to obtain an $88.4 \%$ identification average.

キーワード：手書き文字、筆者識別、オフライン、ストローク形状、類似性評価

\section{1.はじめに}

現代社会では、クレジットカードの利用や施設の入退室 管理、さらに電子商取引き等、非対面取引きの増加に伴い、 コンピュータを用いた迅速かつ正確な個人認識技術の確立 が求められている。

個人を認識、識別する方法として、1)所有物による方法 (磁気カード、ICカード等)、2)知識(記憶)による万法(パス ワード)、3)身体的な特徴による方法(指紋、虹彩等)、4)行 動的な特徵による方法(筆跡、声紋)などが挙げられる。1)、 2)はともに簡易性に優机ているが、盗難、偽造、忘失といっ た危険性があり、3)では心理的抵抗感が大きく、かなり高 機能のハードウエアが必要になる問題点もある。本論文で は、このような問題点の少ない筆跡からのオフライン個人 識別手法について検討した。

筆跡の個人特徵を利用した筆者認識に関する研究(1),(2)は、 入力方式により、オンライン方式とオフライン方式の二種 類に大別される。オンライン方式では文字を筆記する過程 の情報、すなわち、筆順や筆記速度、加速度、筆圧、ある いはペンの角度など動的な情報を個人特摧として利用でき る利点がある。これに対し、既に筆記された筆跡をビデオ カメラなどで取り込み、処理を行うオフライン方式は動的 情報が利用できないという制䄪はあるが、オンライン方式 で用いるような特別な入力装置を必要とせず、事後認証も
可能である。また、オフライン方式の個人識別はオンライ ン方式に比べて利用できる情報量が少なく、より困難であ る。本研究では、この意味で、より一般性に富むとも言え るオフライン入力を仮定する。オフライン方式で入力され た手書き文字からの個人識別が困難なのは、動的情報が利 用できないことのほか、同一人物でも文字画像にばらつき があるためである。

このようなオフライン筆者識別の分野において、相似パ ターンの統計量計測に基づく吉村らの報告(31.44)や、2次統計 量の線分スペクトル分解を用いた尺長らの報告(5)(6)がある。 尺長らは文字画像中にある直線パターンや平行線成分に関 する情報を特徴量として用い、実験的にその有効性を検証 した。さらに吉村らは尺長らの特徽量に円弧パターンの統 計量を加え、曲線性を考慮することでより高精度な筆者識 別が可能であると報告している。

前述の報告(3)ー(6)では手書き文字の個人性という観点から 文字パターンの形状情報の有効性が示されているが、我々 は入力情報のうち、線幅、濃度など筆記具に影響されやす い要素を最小限に抑え、ストロークの基本形状に注目した 手法も可能であると考えた。すなわち、入力画像に細線化 等の㚭理を行うことによりストロークの基本的な形状を抽 出し、これを利用した筆者識別法の開発が可能であると考 えた。このような形状情報はあらゅる筆記デー夕における 基本的な特徴であり、線の太さや濃度といった情報を含ま 
ないため、筆記具などの違いによる影響も受けにくい。

ストロークの基本的な形状に現わ札る個人特徽のうち、之の直 楾性に注目した個人同定手法》はハフ変換により得られる直楾情 報を利用する。直線加得ら机る特徵としては水平方向からのそ の傾き、線分長のほか、勿論、直楾の存在する位置も用いら狄る。 3種類の筆記デー夕、すな⿰ち、

(a)本人署名：筆者 Aによる自己氏名の筆記

(b)単純偽筆：筆者 $\mathrm{A} の$ 筆跡を提示せず、Aの氏名を偽筆者が 筆記

(c)模倣偽筆：筆者 $\mathrm{A} の$ 筆跡提示し、偽筆者が模做して華記 を用意する。(c)ではあらかしめ収集した筆者A本人の筆跡を提示 し、そ扎を見ながら良く真似るよう指示する。デー夕数は、

(a)本人署名：1人の筆者加 70 杴

(b)単純為筆：50人の偽筆者加ら各 1 枚の計 50 枚

(c)模做偽筆：50人の偽筆者加ら各 1 枚の計 50 枚

である。(a)の筆跡から10枚をランダムに選択、本人の筆跡データ ベースを作成し、相互相関をベースとする評価指標を用いて筆跡 全体の照合実娩を行った。照合の判定基準となる閥値の決定に は、データベース作成に使用されたものを除く60枚の本人署名 より、ランダムに選択した10枚を利用した。選択されたた各筆跡 とデータベースとの相互相関の平均と標準偏差を算出し、平均

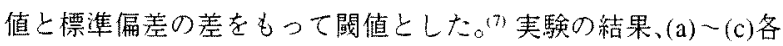
50 枚のテストデータに対し、本人拒否率は平均 $6.8 \%$ 、他人受入 率は(b)で0.0\%、(c)で23.6\%上、単純な特徴の割には良好な成積が 得られている。たたし、こ北筆跡中の直線部が多い漢字で構成 さ扎る筆記デー夕を使用した場合の結果であり、直線部の少ない 平仮名のような字種では抽出ざ狆る個人情報が減少寸るため、成 績が低下する。従って字種によっては直楾性に関する情報だけで 個人識別を行うことは難しく、より高精度な識別能力が要求さ机 るシステムでは他の筆者識別法と組及合わせることが求められ る。この時、処理コストの増大に見合うだけの識別率向上を望む なら、互いに独立な情報をより効果的に組み合わせることが重要 である。

本論文ではこの直線特徽からの個人識別手法を補完する方法と して、筆跡中の曲線部に存在する個人特銜を利用した個人識別手 法について検討した。また、上記の直線性に注目した個人特徴 と、曲楾特徵双方の特徽を利用して筆跡の類似性を評価する手法 についても検討を行った。直線部、曲線部互いに独立な情報とし ての個人特徵を利用することにより、より精度の高い個人識別が 可能になると考之られる。本研究では、筆記ストロークの基本的 な形状に現札る個人の書き方特徵を筆者識別に利用した場合、ど の程度の正確さが得られるかを明らかにすると共に、雨特街を組 み合わせて寒際の筆者識別に利用する可能性の検討を研究の目的 としている。

\section{2. 筆者識別の原理}

\section{$<2.1>$ 個人特徵の記述}

本手法では直線特徵、曲線特徵とも、線の太さ、濃度、文 字と文字との位置関係等に関する情報を用いず、ス卜ロー ク形状に存在する個人特徽のみを利用する。本節では筆記 ストローク中に存在する個人特徽の定義と抽出法について 述へる。
$<2.1 .1>$ 前処理

入力画像は一般性に配慮して白黑濃淡画像とする。まず、 2 值化と細線化処理により同一筆者でもバラつきの大きい 楾の太さや濃度等の影響を排除し、ストロータ情報を取り 出す。原画像、搪大図及び細線化画像の一例を図にに示す。 次に文字单位の筆者識別孝行うため、筆跡画像より個々の 文字を切り出す。文字単位で識別を行う理由は、個々の文

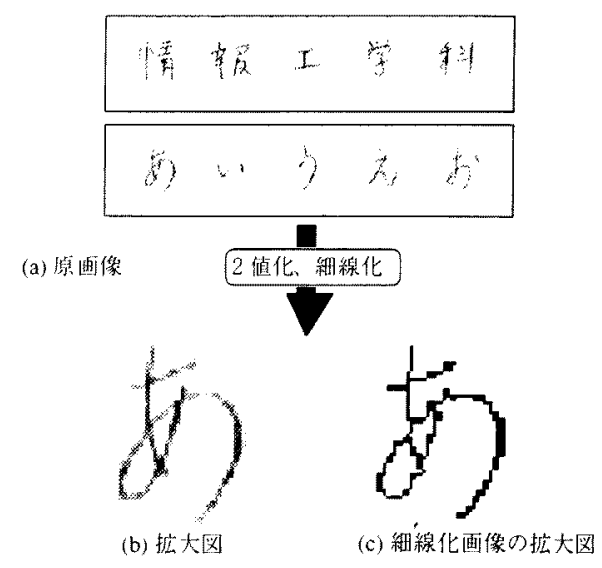

図1 入力画像例

Fig. 1 An example of input images

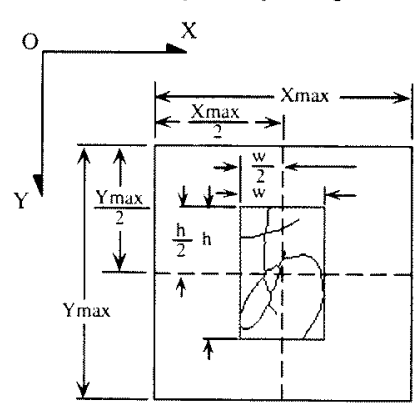

图 2 位哭正规化

Fig. 2 Position normalization

字の構造に依存しない個人の書き方特徵を抽出する際、文 字間距雒(文字バランス) などの情報を排除し、 $<2.1 .2>,<2.1 .3>$ に述べるス卜ローク中の個人特徽を強調す るためである。今回は筆記枠を指定して筆記デー夕を収集 したためセグメンテーションの自動化は行っておらず、入 力画像の縦方向ヒストグラムを利用して分割を行った。文 字ごとに分割された各文字画像は、図2に示すように、外 接する矩形の縦方向、横方向の中央を基準として新たな座 標へ移動するが、この時、拡大や縮小は行わない。 $<2.1 .2>$ 頻度分布の定莪

(1) 直線性頻度分布

前述した通り筆跡の直線部より個人情報を抽出するには、 八フ变換により得られる3次元パラメー夕( $\rho, \theta$, 頻度値) の筆者依存性を利用寸る。ただし、 $\rho$ は原点から直線へお ろした垂線の長さ、 $\theta$ は垂線とx 軸とのなす角である。八 フ曲線の描かれる平面上の各点には筆跡中に含まれる直線 成分の位置、傾き、長さなど直線の状態に関する多くの情 
報が含まれており、筆者固有の書き方特徵となっている。 大部分の筆者は文字、特に漢字、片仮名などを傾けて書く 頋向があり、我々の個人識別法はこの特徽に注目した手法 である。

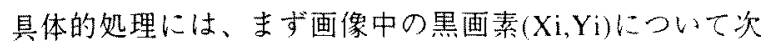
式(1)で表されるハフ变換を適用する。

$$
\rho=X_{1} \cdot \cos \theta+Y_{1} \cdot \sin \theta
$$

画像中の全黑画素について上式を適用すると、 $\rho-\theta$ 平面上 には画素数と同数のハフ曲線が描かれる。ここで $\rho-\theta$ 平面 上のハフ曲線分布を直線性頻度分布と呼び、またその八つ 曲線上の各点 $(\rho \mathrm{j}, \theta \mathrm{j})$ 老特徽点と呼ぶ。特徴点には画像中 保存在する直線成分を成す黑画素数が保存されている。分

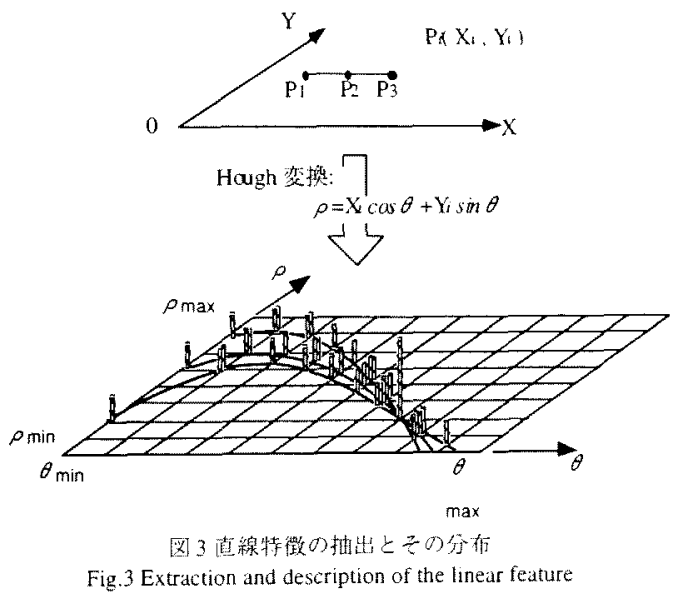

解能 $\theta$ disで $\theta$ をその最小值 $\theta \min$ から最大值 $\theta \max$ まで変

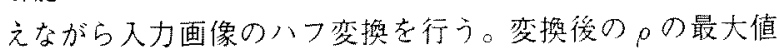
を $\rho \max 、$ 最小值を $\rho \min$ とすれば、次式から、八フ曲線は D個の点集合により記述される。

$$
\mathrm{D}=\left(\rho_{\mathrm{max}}-\rho_{\mathrm{min}}\right) \cdot \theta_{\mathrm{max}} / \theta_{\mathrm{dls}}
$$

すな⿰力口直線成分に関卞石筆者の特徽は次元数Dの特徵 ベタトルで表現される。処理コストを考慮しつつ $\theta$ の分解 能を上げれば次元数が増し、より詳細な個人情報の抽出 分類が可能である。

(2) 曲線性頻度分布

筆跡の曲線部に存在する個人情報として画像に適合する 部分円弧のパラメータ、すなわち曲率円の中心座標 $(\mathrm{x}, \mathrm{y})$ と その頻度を用いる。これは、同種の文字に扮いても筆者毎 に"文字の丸ざが異なって扔り、特に平仮名でこの個人差 が顕著であるという観察結果を数值化する一つの尺度であ る。実際本研究により、当ては如た様々な円の中心座 標とその類度がプロットきれた頻度分布には、ストロータ の全体的な曲率や位置などの情報が反映されており、その 情報を曲線部に存在する個人の書き方の特徽として利用で きることが確かめられた。
円を当てはめる害際の操作は、ストローク中の局所的に 漸結した画素の集合を処理単位として行われる。まず画像 中の1点の黑画素P 0 を選択し、隣接する画素を調心る。。次 いで隣接画素数が2 個の場合のみ、隣接画素に連結した画 素在最大N個まで 8 連結で追跡寸る。2個の隣接画素を始点 とした追跡操作により検出される画素の集合をそれぞれ要

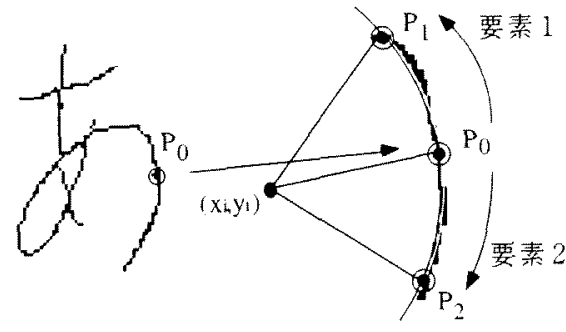

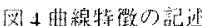

Fig. 4 Description of the curviline ar feature

素1、要素 2 と呼ぶ。次にP0 と要素 1 の点P1、要素 2 の点 P2の3点に円弧を当てはめる(图4)。要素1に含まれる各点 をP1、また、要素 2 に含まれる各点を $\mathrm{P} 2$ とし、この操作を 繰り返す。このときの円の中心座標( xi,yi)の頻度を、曲線性 頻度分布としてプロットしていく。たたし、文字領域の大 きさ（図4の文字「あ」のサイズは $50 \times 73$ pixel）に対し、 特徵分布の領域の大きさは $150 \times 150$ pixel 上平均 6 倍程度 の領域を確保されており、円弧の中心座標はこの領域内に おさまる值だけが特徴として評洒导扎る。実際の処理では 画像中のすべての黑画素をP0として、P0、P1、P2の3点

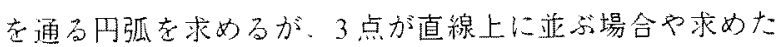
中心が特峌分布領域にない場合には何もせず、次の3点の 組合せを取り出し、同様な処理を繰り返す。このような処 理により文字画像から曲線性頻度分布が求められる。

$<2.1 .3>$ 個人特政の定義

2.1.2で述べた処理により、筆跡の直楾性と曲線性に関亦

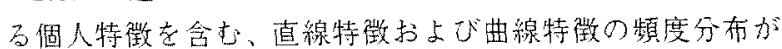
得られる。图 5 に曲線特徽としての円弧の頻度分布の一例 を示す。おおまかな起伏上して筆者の特徽を反昷した頻度 分布が得られている。同時に、起伏に沿った特徵点近傍で は、練かい頻度值の変動が観測できる。このノイズの要因 の一つは量子化誤差である。これは入力画像がドットマト リタスで構成导れる以上必然的に生じるが、この封策とし

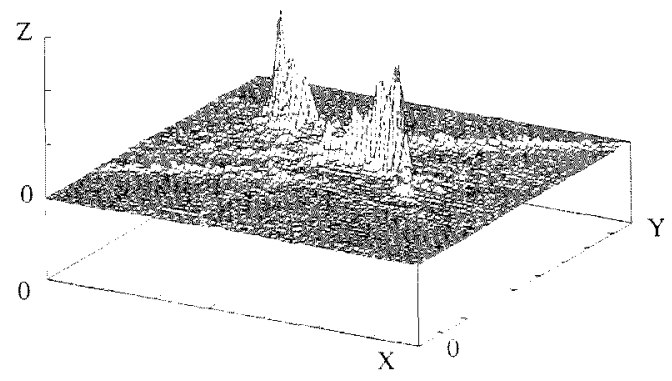

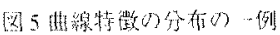

Fig 5 An example of the curvilinear feature distribution 
て一般化ハフ変換に㧍いてピーク形成精度の向上を行う手 法(9)などが報告されている。しかし本研究においては頻度 值のピーク形成精度より、頻度值の分布形状の方が個人情 報として重要である。そこで、処理の簡略化のため、頻度 分布に祄して平滑化処理を施し、処理後に得られるおおま かな起伏を個人特徵として採用する。以下では、登録者 $\mathrm{p}$ の k番目の筆跡中の $\mathrm{n}$ 番目の文字より抽出された直線性に関す る個人特徴を、

$$
\begin{aligned}
& \operatorname{SF}_{p k n}(\rho, \theta), \\
& \left(\rho_{\min } \leq \rho \leq \rho_{\max }, \theta_{\min } \leq \theta \leq \theta_{\max }\right)
\end{aligned}
$$

同様に、曲線性に関する個人特徵を、

$$
\begin{aligned}
& \mathrm{CF}_{p, k, n}(x, y), \\
& \left(x_{\min } \leq x \leq x_{\max }, y_{\min } \leq y \leq y_{\max }\right)
\end{aligned}
$$

と表記する。

\section{$<2.2>$ 識別方法}

筆者の識別は、複数枚の参照用筆跡を利用した類似性評 価に基づいて行われる。本節では、参照用の筆跡より登録 者の平均的な特徽を記述したデー夕(基準データ)を作成す る方法と、類似性の評価方法について述べる。

$$
<2.2 .1>\text { 基準データ }
$$

同一筆者においても筆跡には若干のばらつきがあるため、 基準データの設定に際してはこの変動を考慮することが重 要である。つまり、筆跡の变動を考慮に入れた平均的な特 徽を特定個人の基準データとして記述する必要がある。本 手法では以下の手順で、複数の参照用筆跡から基準デー夕 を作成する。

まず、各参照用筆跡から、2.1で述べた方法に従って直線 性扔よび曲線性に関する個人特徽、SF $p, k, n(o, \theta) 、 \mathrm{CF} p, k, n$ $(x, y)$ を抽出する。ここで $\mathrm{p} は$ 登録者番号、kは参照用筆跡に 扮ける筆跡番号、またn笹跡中の文字番号を示す。

次に筆者 $\mathrm{p} に よ る \mathrm{~K}$ 個の文字についての、平均と分散を 求める。直楾特徽の分散値の分布を V_SF $p, n(\rho, \theta)$ 、平均 值の分布をM_SFp, $n(\rho, \theta)$ 、同様に、曲線特徵の分散值の 分布を V_CFp, n $(x, y)$ 、平均值の分布を $M_{-}$CF p,$n(x, y)$ とする と、

$$
\begin{aligned}
& \mathrm{M}_{-} \mathrm{SF}_{p, u}(\rho, \theta)=\frac{1}{\mathrm{~K}} \sum_{k=1}^{\mathrm{K}} \operatorname{SF}_{p, k, n}(\rho, \theta) \\
& \mathbf{M}_{-} \mathrm{CF}_{p, n}(x, y)=\frac{1}{\mathrm{~K}} \sum_{k=1}^{\mathrm{K}} \mathrm{CF}_{p, k, n}(x, y) \\
& V_{-} \operatorname{SF}_{p, n}(\rho, \theta)=\frac{1}{\mathrm{~K}} \sum_{k=1}^{K}\left(\operatorname{SF}_{p, k, n}(\rho, \theta)-\mathrm{M}_{-} \operatorname{SF}_{\rho, n}(\rho, \theta)\right)^{2} \\
& \mathrm{~V}_{-} \mathrm{CF}_{p, n}(x, y)=\frac{1}{\mathrm{~K}} \sum_{k=1}^{\mathrm{K}}\left(\mathrm{CF}_{p, k, n}(x, y)-\mathrm{M}_{-} \mathrm{CF}_{p, n}(x, y)\right)^{2}
\end{aligned}
$$

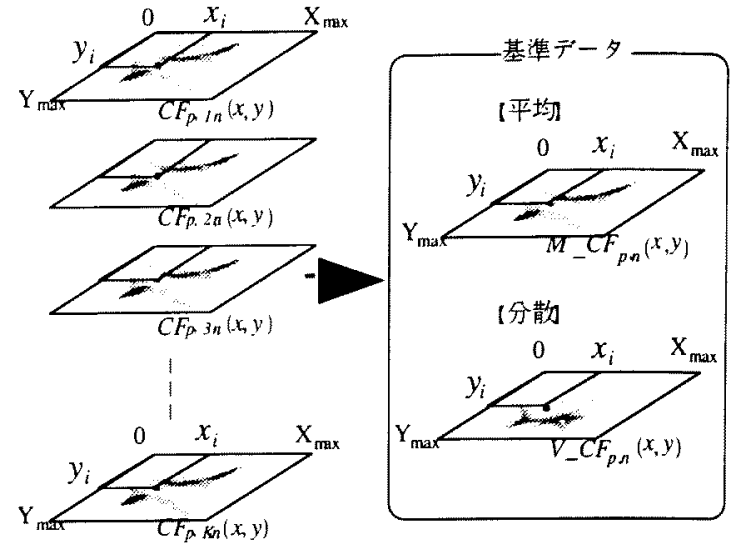

図 6 基集データについて

Fig.6 Individual standard data for comparison

となる。以上の操作により基準デー夕を作成する。この基 準デー夕作成法を図6に示す。

\section{$<2.2 .2>$ 距離計算}

筆者未知のテストデータと登録者ごとの基準データとの 類似性評価の尺度として分散值で重み付けしたEuclid距離 (6)を用い、次式により直線特徵についての距離 SL p,n之曲線 特徵についての距離 CL p,nを算出する。

$$
\begin{aligned}
& \mathrm{SL}_{\rho, n}=\sum_{\rho} \sum_{\theta} \frac{\left\{\mathrm{ST}_{n}(\rho, \theta)-\mathrm{M}_{-} \mathrm{SF}_{p, n}(\rho, \theta)\right\}^{2}}{{\mathrm{~V} \_S F_{p, n}}_{(\rho, \theta)}} \\
& \mathrm{CL}_{p, n}=\sum_{x} \sum_{y} \frac{\left\{\mathrm{CT}_{n}(x, y)-\mathrm{M}_{-} \mathrm{CF}_{p, n}(x, y)\right\}^{2}}{\mathrm{~V}_{-} \mathrm{CF}_{p, n}(x, y)}
\end{aligned}
$$

この評価方法では登録者が複数回筆記する時の、各特徴点 における変動のし易さに応じて重子付けを変え、平均的な 特徵間の距離を求める。ここで、評価対象となる直線特徵 の次元数は、入力画像のサイズと八フ変換の分解能を考慮 して $720 \times 360$ 、また曲線特徵の次元数は $150 \times 150$ である。 $<2.2 .3>$ 総合評価

上記の処理により、直線特徽の距離 SL $p, n$ と、曲線特徽 の距離CLp,nが求めら扎る。こ札らの距離から筆跡間の棇合的な 類似性評価を行うが、SL $p, n$ と $\mathrm{CL}_{p, n}$ の距離ではスケールが異なる ため、距離指標統合のための工夫が必要となる。ここでは、次式 の基準値により両距離を標準化する評価法(6)を用いた。すなわ ち、

$$
\mathrm{L}_{p, n}=\frac{\mathrm{SL}_{p, n}}{\mathrm{SL}_{0}}+\frac{\mathrm{CL}_{p, n}}{\mathrm{CL}_{0}}
$$

として求めら礼るLp,nによりテストデータと基準データとの 類似性を評価する。ここで基準值としては、4.2の検討結果から 最小値を採用した。すなわちSL0はSLp,n(p:1一登録者数)の最小 值、同様にCLOは CLp,nの最小值である。式(9)により算出され る距離は、直線、曲楾特徴の双方において最小值を与える登録者 の場合に最小値 2 となり、原理的には2 2 以上の有限值を取る。

\section{3. 識別実験}

$<3.1>$ 筆跡データ 


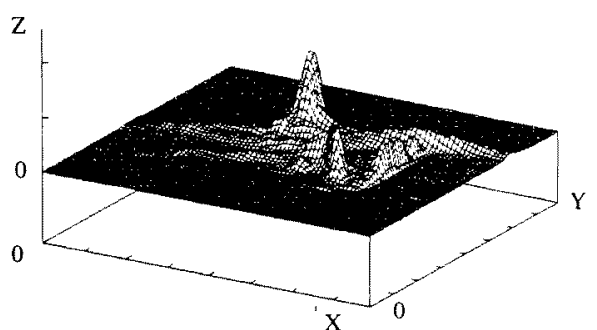

(a)

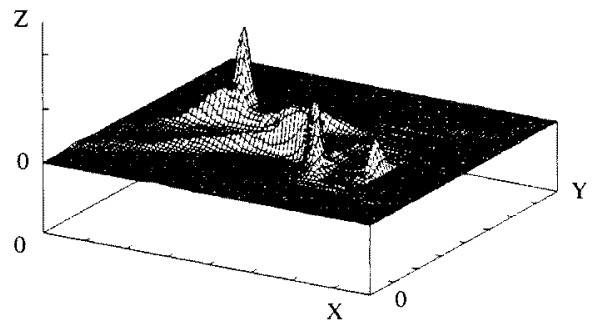

(c)

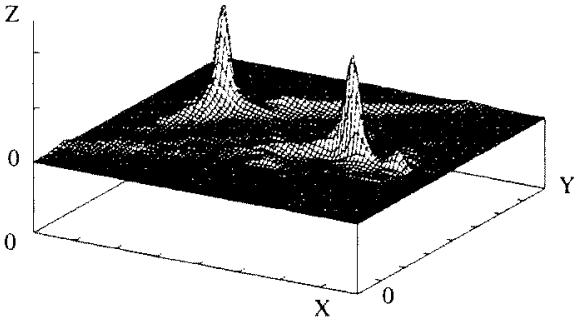

(b)

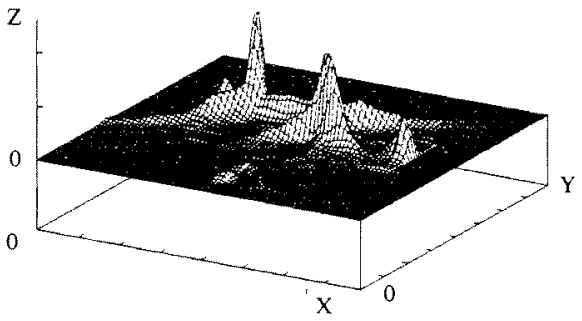

(d)

图 7 曲線特徽の個人倳

Fig. 7 Individual variation in curvilinear features

筆記用紙には筆記の極端な妨げとならない程度の大きさの筆跡 枠を設け、枠内に筆記するよう指示した。書かれた文字は筆記用 紙毎にスキャナで取り込ま机るが、その解像度は170DPI(図1に 示した「あ」で $50 \times 73$ pixel）である。入力画像から文字を切り 出し、文字位置を正規化し $150 \times 150$ pixel の画像平面上に再配 置する。

筆記データとしては、2種5 文字からなる「情報工学科」上「あ いうえお」の文字列を、1 日5枚の上限を設けて7人の登録者よ り15枚ずつ収集した筆跡を用いた。

\section{$<3.2>$ 個人特徴の抽出}

直線特徽を抽出する際の分解能を $\theta$ dis $=0.5^{\circ}$ 、また、曲楾特徴 抽出の処理単位となる連結要素の最大追跡数を $\mathrm{N}=8$ としてそ扎 ぞ㧈の特徵を抽出した。また各特徽について行う平滑化処理に は、4.1の検討結果からサイズ $5 \times 5$ の平均值フィルタを用いた。 ここで、文字「あ」について曲線性に関する個人特徴を求めた例 を図7に示す。図7(a) 一 (d)に示す個人特徽は異なる4名の筆者の そ扎である。大局的には似た形状であるが、同時に筆者による違 いも明瞭である。

\section{$<3.3>$ 実験方法}

筆者識別実験では、グループ中にテストデータの筆者が確実に 存在するという仮定のもと、各登録者についてあらかじ準備し た基準デー夕を用い、テストデー夕の文字ごとに筆者を識別す る。テストデータが入力さ机ると、まず、細線化など前処理を行 い、文字単位に分割された各入力画像から直線性ならびに 曲線性に関する特徵抽出を行う。細線化にはHilditchの才 ペレー夕181を用いた。各登録者の基準データと抽出された 直線および曲楾特徽との距離を式(9)より求め、距離が最小 となる基準データの登録者を筆者と判定する。

3.1 で説明したように、各登録者による筆記データが15枚 ずつ存在する。今回の識別実験では、この15枚の筆記デー 夕のうち9枚をランダムに選択して基準データを作成し、 残りの6枚をすべて筆者末知のテストデータとして用いた。

基準デー夕を作成する際に用いる9個の筆記データの選
素1平均譏别精度

Table 1 Averaged correctness of identification

\begin{tabular}{|c|c|c|c|c|c|}
\hline 文字 零䮬番号 & (1) & (2) 3 & (4) & (5) & 平均正答新\%) \\
\hline 情 & 85.71 & $95.24 \quad 90.48$ & 88.10 & 85.71 & 89.05 \\
\hline 督 & 80.95 & $80.95 \quad 83.33$ & 80.95 & 83.33 & 81.90 \\
\hline$I$ & 76.19 & $\begin{array}{lll}78.57 & 80.95\end{array}$ & 73.81 & 83.33 & 78.57 \\
\hline 学 & 95.24 & $92.86 \quad 85.71$ & 95.24 & 90.48 & 91.91 \\
\hline A & 76.19 & $90.48 \quad 85.71$ & 85.71 & 80.95 & 83.81 \\
\hline あ & 88.10 & $95.24 \quad 95.24$ & $92.86 \mathrm{I}$ & 10000 & 94.29 \\
\hline w & 90.48 & $92.86 \quad 95.24$ & 92.86 & 92.86 & 92.86 \\
\hline j & 80.95 & $83.33 \quad 85.71$ & 80.95 & 83.33 & 82.85 \\
\hline$\dot{z}$ & 85.71 & $92.86 \quad 95.24$ & 90.481 & 100.00 & 92.86 \\
\hline 椋 & 92.86 & 100.0097 .62 & 92.86 & 97.62 & 96.19 \\
\hline 平场值 & 85.24 & $90.24 \quad 89.52$ & 87.38 & 89.76 & 88.43 \\
\hline
\end{tabular}

び方により、識別精度は多少変化する。5回にわたる識別実 験の結果を表 1 に示す。7人の登録者の筆跡6枚ずつを識別 对象として挰り、各識別実験におけるテストデータの数は 42 個となっている。平均正答率 $88.43 \%$ という結果が得ら れたこと、また特に比較的曲線部の多いデー夕「あいうえ お」についても、漢字データと同様、あるいはより良好な 結果が得られたことから、筆跡の直線性と曲線性に関する 個人特徵を識別に用いた本手法の有効性が確認できた。

\section{4. 検討}

\section{$<4.1>$ 平滑化処理}

直線、曲線特徽を抽出する際、頻度分布に対して平滑化 処理を行った。これは頻度分布に筆者の特徽がおおまかな 起伏として現かれるか、細かく不規則的に発生する起伏は 量子化䛊差などにより生じ、識別にとってはノイズにすぎ ないと考えたためである。

このようなノイズの成因の具体例を図8に示す。図 8 で 
は、2值化、拉よび細線化処理後の画像パターンがP2で構 成される場合とP2 で構成される場合の二つの場合を示し ている。つまり(P0,P1,P2)、(P0,P1,P2')の2 パターンから円 中心座標を求めた場合、それぞれの中心座標が異なってい

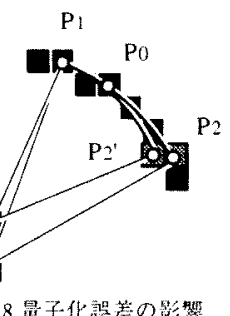

Fig. 8 The influence caused by quantization error

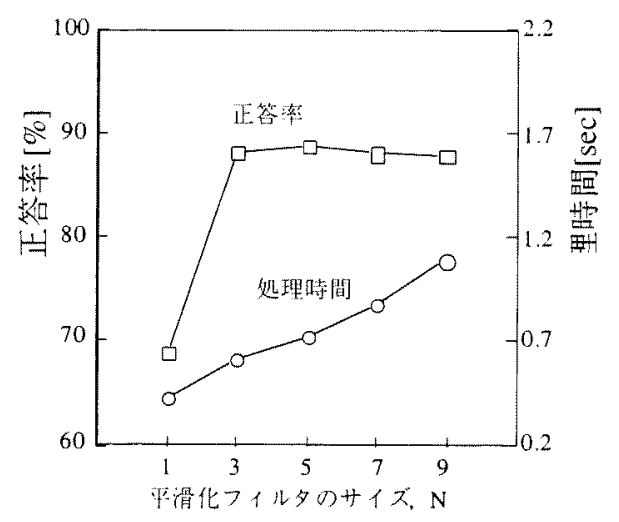

图 9 平滑化処理に上る縕別精度の变化

Fig. 9 Smoothing and correct identification rates

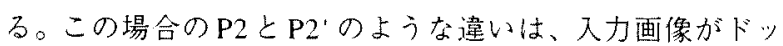
トマトリクスで構成されるため一定の確率で必然的に生じ るものであり、その対応策として平滑化処理を施した。

しかし、平滑化の程度を少しずつ強めてゆく、すなわち フィルタサイズを大きくしていくとある程度まではノイズ 除去により識別精度が向上するが、一定以上のサイズでは 個人特徵に関する情報も失わ机る可能性がある。そこで フィルタサイズを少しずつ变えて実際に筆者識別実験を行 い、平滑化処理における最適フィルタサイズを決定した。 平滑化には平均值フィルタを使用し、平滑化なしのサイズ 1×1から2ずつフィルタサイズを拡大していき、全てのテ ス卜文字の平均正答率、および 1 文字あたりの特街抽出処 理時間の変化をプロットしたのが図9である。予想通り、平 滑化操作によって正答率は大きく向上するが、サイズ $5 \times 5$ のフィル夕を頂点としてその効果は低下している。この検 討結果を踏ま之、本研究ではサイズ $5 \times 5$ の平均值フイル 夕を用いてノイズ除去を行った。

$<4.2>$ 総合評価方法

本手法では直線特徽の距離SLと曲楾特徴の距蜼 CL、2つ の距離加棇合的な距離を求め、テストデー夕上各登録者 の基準データとの最終的な類似性評価を行う。しかしSLと CLではスケールが異なるため、両者を統合した新たな指標 が必要となる。
そこで、式(9)のように基準值(SLO,CLO)により標準化した SLとCLの線形和で釉合評価を行う方法について検討した。 具体的には、まず各登録者について得られた距離より中央 值、最小值、平均值を特徽別に求める。そして各值を基準

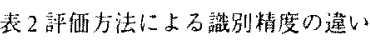

Table 2 Estimation method and correct identification rates

\begin{tabular}{|c|c|c|c|}
\hline 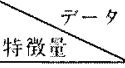 & "1 封郝工学科" & "あいうえお゙ & 事均正答策 $[\%]$ \\
\hline Lcen,p & 81.63 & 89.25 & 85.44 \\
\hline Lmin,p & 83.88 & 90.27 & 87.08 \\
\hline Lave,p & 81.63 & 89.32 & 85.48 \\
\hline 直楾特徽 & 75.96 & 65.96 & 70.96 \\
\hline 曲秘特特微 & 67.62 & 82.50 & 75.06 \\
\hline
\end{tabular}

值(SL0,CLO)とした場合の総合評価法をそれぞれLcen,p、 Lmin,p、Lave,p と定義し、識別精度の比較実駼を行った。

これら 3 通りの総合評洒法による識別結果評価法の有効 性確認のため、従来我々が用いてきた直線特徽に基づく評 洒法(7、拉よび本研究で開発した曲線特徴に基づく評価法 をそれぞ狆単独で谪用した場合に得られた結果を表 2 に示 す。総合評洒法では、Lmin,pで最も良い結果が得られたた め、文献(6)と同様に最小值で標準化した両距離の線形和で あるLmin,pを棇合評価指標とした。

直線性と曲線性の特徽を単独で評洒した識別結果と比較 し、直線部の多いデータ"情報工学科”、また曲線部の多い データ"南いうえ扔”の双方で、総合評価指標を用いること により識別精度は大きく向上していることが分かる。以上 の結果から、筆跡の直線部抢よび曲線部から個人の書き方 の特徽を抽出する筆者識別法の有効性が確認できる。 $<4.3>$ 処理コスト

本手法を用いた場合の処理コストについて検討する。識 別に必要な処理時間と記憶容量はプログラム構造と計算機 性能にも依存するが、参考までに実際に各デー夕算出に要 した処理時間上記憶容量を表 $3 に$ 示す。計算機はFujitsu S7/400U(CPU:UltraSPARC-II 300MHz)を用いた。な拉、処理 時間や記憶容量は文字、あるいは筆記者により多少の違い があるため平均值を記した。なお、特徽平面においては変 化の少ない部分が多いため、同じ数值が連続する場合その 連続数を格郝する簡単な圧縮プログラムを使用した。压縮 率は曲線特徵、直線 特徽、基準データに依存して変化する が、結果的には、概权、65～90\%程度となっている。

例えばN人の登録者が存在して5字からなる筆記デー夕 の各文字について識別を行う場合、表 3 より処理時間は、

$$
\mathrm{T}=5 \times\{\mathrm{t} 1+\mathrm{t} 2+\mathrm{N} \times \mathrm{tc}\}
$$

記憶容量は、 
表 3 処理時間と必要記憶容量

Table 3 Processing time and required memory size

\begin{tabular}{|c|c|c|}
\hline 処理内容 & 処理時間 [sec] & メモリ容量 $[K B]$ \\
\hline 曲線特徵の抽出 & $0.13 \quad(\mathrm{t} 1)$ & $63 \quad(\mathrm{cl})$ \\
\hline 直楾特徵の抽出 & $0.58 \quad(\mathrm{t} 2)$ & $195 \quad(\mathrm{c} 2)$ \\
\hline 基準データ作成 & 1.50 & 677 (cb) \\
\hline 類似度の計算 & $1.87 \quad$ (tc) & \\
\hline
\end{tabular}

$$
\mathrm{C}=5 \times\{\mathrm{cl}+\mathrm{c} 2+\mathrm{N} \times \mathrm{cb}\}
$$

となり、処理コストは、約 $(9.4 \mathrm{~N}+3.6)$ 秒、約 $(3385 \mathrm{~N}+1290)$ $\mathrm{KB}$ と概算できる。

現在、本手法のソフトウェアは計算速度よりもデバッグ や变更が容易に実行できるようなプログラム構造となって おり、かなりて長性があることを考慮すれば、識別の正答 率が表1のような值で許される用途に対しては、実用化が 可能な範囲の処理コストであると考えられる。

\section{5.おわりに}

手書き文字中の直線部と曲線部に存在する個人特徵を、 ハフ変換、および文字画像中の曲線部への円のあてはめに より求める手法について検討した。本手法の特徽として、 細線化した入力画像から情報を抽出するため、線幅や濃度 といった筆記具に依存する不安定な情報を排除でき、ス卜 ローク形状より個人特徽を抽出するために、処理コストを 低減できることが挙げられる。直線、曲線、何れも単純な 特徴量の割には共に $70 \%$ 以上の識別率が得られることを明 らかにした。また、個人識別という目的に沿って両特徵を 統合すると、簡単なアルゴリズムの割には筆者識別実験で 平均約 $88.43 \%$ の正答率が得られ、本手法の有効性が確認で きた。

本研究で提案した曲線性に注目した個人特徵には、

1)ストロークの曲率が小さい、すなわち当てはめる円の半 径が大きいほど量子化誤差の影響が大きい

2)異なるストロークから同樣の中心位置が求まった場合で も、その情報を区別することができない

3)入力画像に適合する円弧の中心座標が既定の範囲を超え た場合、曲線性に関する特徵の一部が久落する

問題が残されている。このうち、3)については、今回は文 字画像のサイズ(図 1 の文字「あ」で50×73pixel)に対して 倍程度の大きさをもつ領域 $(150 \times 150$ pixel $)$ を考慮すること により対応した。特徴の欠落を完全に防ぐことは不可能で あるが、曲線特徵の記述に十分な領域を実験的に決定する ことである程度の対処は可能である。この問題は、上記1)、

2)も含めて今後の課題である。

(平成 11 年 5 月 17 日受付、平成 11 年 10 月 4 日再受付)

\section{文献}

(1) R.Plamondon and G.Lorette, "Automatic signature verification and writer identification-The state of the art," PR, Vol.22, No.2, pp.107-131,(1989).

(2) 吉村ミッ，吉村功、「筆者認識技術の現段階と今後の動向」，信学技坡、 Vol.96, No. 141 (PRMU9637-48), pp.81-90,(1996).

(3) 吉村ミッ, 吉村功, 「相似バターンの頻度による筆者蓄別」, 信学論 (D II). Vol. J72-D-II, No.12, pp.2051-2060, (1989-12).

（4）吉村ミッ，吉村功，「局所円弧バターン法を用いた筆者識別」，信学論 (II), Vol. J74-D-II. No.2, pp. 230-238, (1991-2).

(5) 尺長健,金子博，淀川英司，「2 次統計量の線分スペクトル分解」,信 学論 (D), Vol. J67-D, No.4, pp. 488-495, (1984-4).

(6) 尺長 健, 金子博，淀川英司，「2 次統計量の線分スペクトル分解によ る手書き文字の筆者認識」,信学論 (D), Vol. J67-D, No. 7, pp. 776-783, (19844).

（7）石渡正倫，宮川道夫，「Hough変換による手書き文字の筆者同定」，信学 技報，IE95-111, (1995-12).

(8) C.J.Hilditch, "Linear skeleton from square cupboards", in Machine Intelligence, Vol. 6, Edinburgh Univ. Press, pp.403-420, (1969).

（9）森本正志, 末永尿仁，「曲線こう配の誤差解所に基づく可变一般化八〉 变換」, 信学論 (D -II), Vol. J81-D-II, No.4, pp.593-601, (1998-4).

(10) 瀨戸洋一,「パイオメトリクスを用いた本人認証技術」, 計測制御, Vol. 37 . No.6. pp. 395-401, (1998-6).

(11) R.N.Nagel and A.Rosenfeld,"Computer detection of freehand fogeries," IEEE Trans. Comput., Vol. C-26, No. 9, pp.895-905, (1977-9).

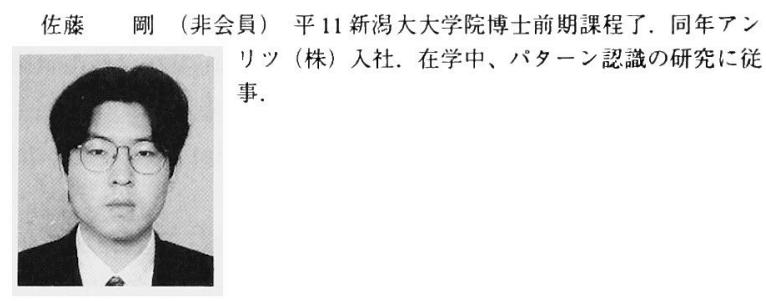

宮川 道夫 (正員) 昭 40 - 43日立製作所勤務. 昭 52北大大学院 (電 子) ·博士課程了. 工博. 同年電子技術総合研究所入 所, 電子計算機部, 光技術部主任研究官を経て, 平 3新潟大学工学部教授. マイクロ波CTによる生体情 報の可視化や電磁波被曝量の可視化, 電磁環境設 計、およびヒューマンインターフェース等の研究に 従事. IEEE, 日本ME学会, 電気学会, 情報処理学 会, 計測自動制御学会, 日本ハイパーサーミア学会 等の会員. 平成 7 年 3 月 平成 8 年 1 月、ウルム大学 ハイイオメ゙ィカル中央研究所客員研究員.

石渡 正倫 (非会員) 平6数潟大.工・情報卒. 平8同大大学院修

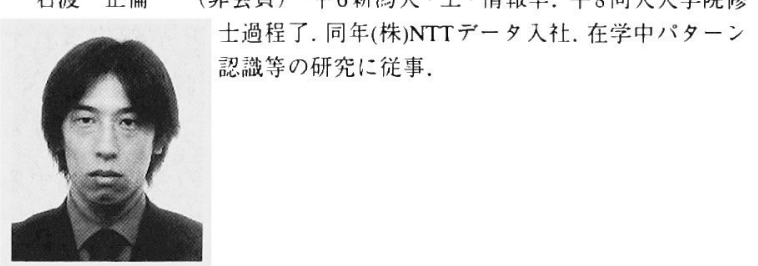

